\title{
Method for the Analysis of 8-Hydroxy-2'-deoxyguanosine in Urine by Gas Chromatography
}

\author{
Surong MEI,*,** Guowang Xu,** Jun XING,* and Caiying WU ${ }^{* \dagger}$ \\ *College of Chemistry, Wuhan University, Wuhan 430072, China \\ **National Chromatographic Research and Analysis Center, Dalian Institute of Chemical Physics, \\ Chinese Academy of Science, Dalian 116011, China
}

(Received December 4, 2000; Accepted March 5, 2001)

\begin{abstract}
Oxidative damage to DNA is considered to be important in mutagenesis, carcinogenesis and the ageing process. ${ }^{1,2}$ Of about 20 major oxidative DNA adducts that have been characterized, ${ }^{3}$ 8-hydroxy-2'-deoxyguanosine (8OHdG) has received considerable attention due to its demonstrated mutagenic potential, ${ }^{1,4,5}$ which has been shown to cause the $\mathrm{GC} \rightarrow \mathrm{TA}$ transversion. ${ }^{6,7}$ It is worth mentioning that many $\mathrm{GC} \rightarrow \mathrm{TA}$ transversions have been detected in $\mathrm{p}^{53}$ genes (an important carcinogenic gene) isolated from human lung and liver cancers. ${ }^{8}$ This result suggests that $8 \mathrm{OHdG}$ may be a good marker of carcinogenesis.
\end{abstract}

Since oxidative damage to DNA is a continuous process, intracellular repair mechanisms have evolved to avoid the rapid and lethal accumulation of oxidative DNA damages. In the case of $8 \mathrm{OHdG}$, the experimental evidence indicates that mammalian cells possess nonspecific (excinucleases) and specific (glycosylases) DNA repair enzymes that can excise this modification, which is subsequently excreted in urine as nucleoside or free base without any further metabolism. ${ }^{9-11}$ The determination of urinary $8 \mathrm{OHdG}$ has thus been proposed as a noninvasive assay of in vivo oxidative DNA lesions. Loft et al. have reported that smokers excrete $50 \%$ more urinary $8 \mathrm{OHdG}$ than nonsmokers. This indicates a $50 \%$ increased rate of oxidative DNA damage from smoking. ${ }^{12}$ The urinary $80 \mathrm{OHdG}$ levels in patients with gynecologic cancer ${ }^{13}$ and non-insulindependent diabetes mellitus ${ }^{14}$ are also significantly higher than that in control subjects.

At present, several methodologies for measuring $8 \mathrm{OHdG}$ have been developed, including high-performance liquid chromatography (HPLC) with electrochemical (EC) detection and gas chromatography/mass spectrometry (GC/MS). Although HPLC-EC is a highly sensitive method for the analysis of $8 \mathrm{OHdG}$, the applicability of this method is not as general as that expected from a suitable and sensitive GC/MS method. To the best of our knowledge, there have been a few reports concerning the analysis of urinary $8 \mathrm{OHdG}$ by GC/MS. ${ }^{15,16}$ However, for a method before GC analysis of the products of oxidative DNA damage can be accomplished, these compounds must first be converted to volatile derivatives with suitable chromatographic properties. Among various derivatives of nucleoside, the trimethylsilyl (TMS) derivative is the most suitable to work for the derivatization of nucleosides when compared to other derivatives. Although there are a few

$\doteqdot$ To whom correspondence should be addressed. reports of studied concerning the best reaction condition for the derivatization of normal nucleosides with TMS reagents, ${ }^{17,18}$ these investigations were carried out at the milligram level.

Here, we report on an optimization of the derivatization procedure while focusing on sub-microgram levels of $8 \mathrm{OHdG}$ with TMS reagents, bis(trimethylsilyl)trifluoroacetamide (BSTFA). An optimal method is established to analyze urinary $8 \mathrm{OHdG}$ by GC and a single-step solid-phase extraction. This method has been successfully applied to the detection of $8 \mathrm{OHdG}$ in spiked urine. In general, the results show that it is possible to provide a noninvasive assay for an indirect measurement of oxidative DNA damage.

\section{Experimental}

\section{Chemicals}

Bis(trimethylsilyl)trifluroacetamide (BSTFA) was purchased from Merck. 8-Hydroxy-2'-deoxyguanosine (8OHdG) was from Sigma (St. Louis, MO, USA). Solid-phase extraction columns $\left(\mathrm{C}_{18} / \mathrm{OH}, 500 \mathrm{mg}, 6 \mathrm{ml}\right)$ were obtained from Chrom. Expert Com. USA. Methanol and acetonitrile $\left(\mathrm{CH}_{3} \mathrm{CN}\right)$ were of high-performance liquid chromatography(HPLC)-grade. All other reagents used were of analytical grade.

\section{Apparatus and conditions}

A Shimadzu Model 17A gas chromatograph equipped with a flame ionization detector (FID) and a Shimadzu CR-7A recorder was used. The temperature of the injection port was $300^{\circ} \mathrm{C}$ and that of the detector was $310^{\circ} \mathrm{C}$. Separations were carried out on a J \& W DB-5MS capillary column $(24 \mathrm{~m} \times 0.25$ $\mathrm{mm}$ i.d., film thickness $0.25 \mu \mathrm{m})$. The separation condition was optimized with respect to the column temperature; the final optimized column temperature was held at $210^{\circ} \mathrm{C}$ for $5 \mathrm{~min}$, raised at a rate of $10^{\circ} \mathrm{C} \mathrm{min}-1$ to $270^{\circ} \mathrm{C}$, and held for $5 \mathrm{~min}$. Hydrogen was used as the carrier gas at an average linear velocity of $52 \mathrm{~cm} / \mathrm{s}$; the split ratio was $15: 1$. Mass spectra were taken at $70 \mathrm{eV}$ on a Shimadzu Model QP-5000 mass selective detector interfaced to another 17A gas chromatograph. The temperature of the interface port was $260^{\circ} \mathrm{C}$. Helium was used as the carrier gas. The other separation conditions were similar to that for GC/FID.

Urine sample collection and solid-phase extraction (SPE)

Urine samples from nine healthy persons (four women, five 

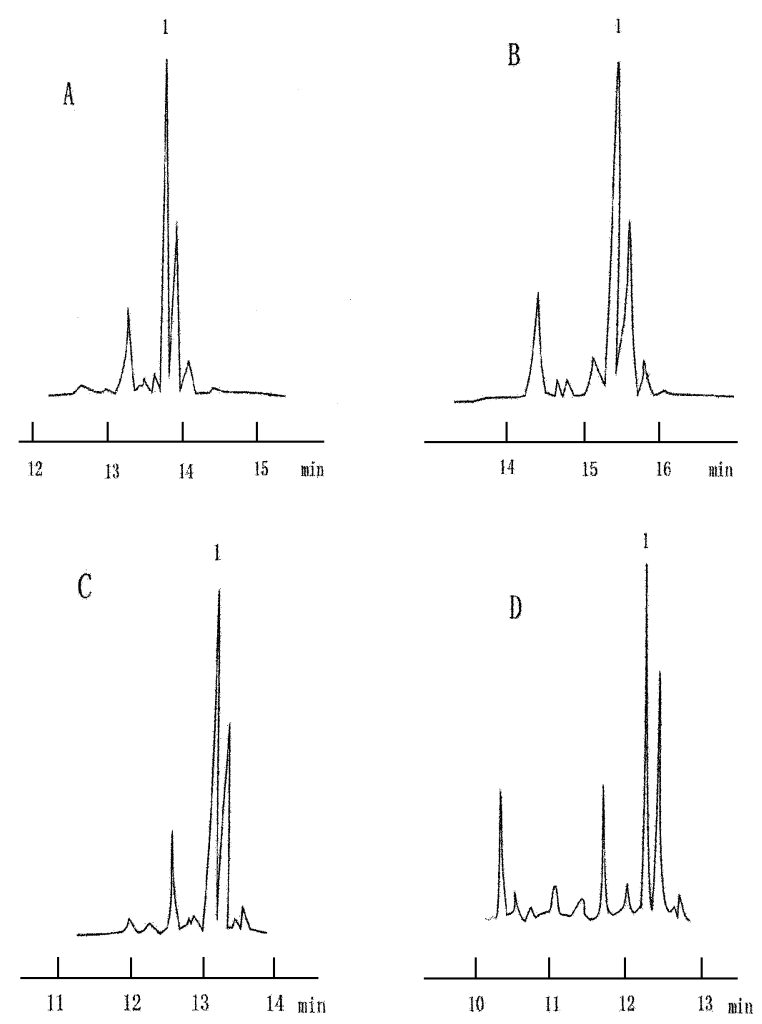

Fig. 1 Effect of the column temperature on the separation of $8 \mathrm{OHdG}$ from other urinary components. Column temperature condition: initial temperature, $210^{\circ} \mathrm{C}$ held for $5 \mathrm{~min}$; final temperature, $270^{\circ} \mathrm{C}$ held for $5 \mathrm{~min}$. Temperature program rate: A, $7^{\circ} \mathrm{C} / \mathrm{min}$; $\mathrm{B}, 5^{\circ} \mathrm{C} / \mathrm{min} ; \mathrm{C}, 8^{\circ} \mathrm{C} / \mathrm{min} ; \mathrm{D}, 10^{\circ} \mathrm{C} / \mathrm{min}$. Peak 1 represents $8 \mathrm{OHdG}$.

men) were pooled together and used for developing the samplepreparation steps. After the $\mathrm{pH}$ of the urine was adjusted to about 7 by the addition of dilute $\mathrm{HCl}, 5 \mathrm{ml}$ aliquots of urine were kept frozen at $-20^{\circ} \mathrm{C}$. Each sample was thawed and centrifuged at $2000 \mathrm{~g}$ for $10 \mathrm{~min}$ to remove any precipitates before the cleanup procedure by solid-phase extraction. The $\mathrm{C}_{18} / \mathrm{OH}$ columns were preconditioned with $10 \mathrm{ml}$ methanol, 10

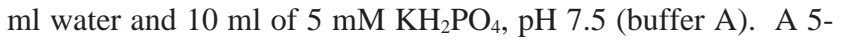
$\mathrm{ml}$ volume of urine spiked with a $2.5 \mathrm{ml}$ certain concentration $8 \mathrm{OHdG}$ standard and premixed with $2.5 \mathrm{ml}$ of $2 \mathrm{M} \mathrm{NaCl}$ was applied to the column. The column was washed with $3 \mathrm{ml}$ of buffer $\mathrm{A}$, and $8 \mathrm{OHdG}$ was eluted with $3 \mathrm{ml}$ of $15 \%$ methanol in buffer $\mathrm{A}$. The eluate was then mixed with $6 \mathrm{ml} \mathrm{CH}_{3} \mathrm{CN}$ and was centrifuged at $2000 \mathrm{~g}$ for $5 \mathrm{~min}$. After that, the eluate was evaporated to dryness under vacuum at $39-40^{\circ} \mathrm{C}$ and the residue was dissolved in $0.5 \mathrm{ml}$ methanol.

\section{Preparation of trimethylsilylated derivatives}

The final methanol solution of SPE was transferred into a derivatization glassware, and the organic phase was evaporated to dryness at $39-40^{\circ} \mathrm{C}$ under a stream of nitrogen. The residue was trimethylsilylated with a $50 \mu \mathrm{l}$ mixture of BSTFA and $\mathrm{CH}_{3} \mathrm{CN}(2: 1, \mathrm{v} / \mathrm{v})\left(1 \mathrm{ml} \mathrm{CH} \mathrm{CH}_{3} \mathrm{Containing} 250 \mu \mathrm{g}\right.$ pyrene as an internal standard) by heating for $1 \mathrm{~h}$ at $100^{\circ} \mathrm{C}$.

\section{Reproducibility of the method}

Aliquots containing $0.5 \mu \mathrm{g}$ of $8 \mathrm{OHdG}$ were used to investigate the reproducibility of this method. The result of the reproducibility was obtained for the derivatization of $8 \mathrm{OHdG}$ in

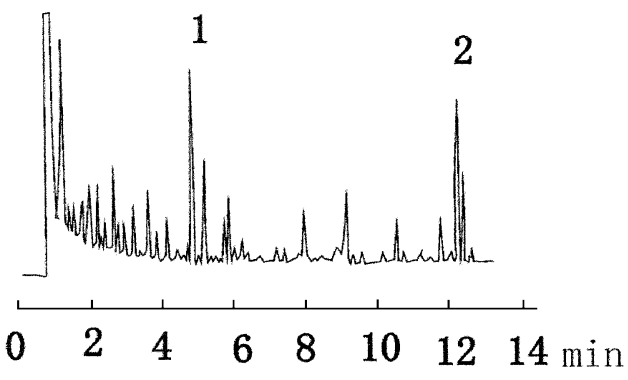

Fig. 2 Gas chromatogram of a spiked urine sample. The column temperature condition was as shown in Fig. 1D. Peaks 1 and 2 represent pyrene and $8 \mathrm{OHdG}$, respectively.

intraday and interday replicate experiments. The reproducibility was determined on the basis of the coefficients of variation.

\section{Results and Discussion}

Optimization of solid-phase extraction

In this method, the SPE condition was optimal and the developed one-step SPE was efficient for purifying $80 \mathrm{OhdG}$ from urine. However, during the last decade, purifying $8 \mathrm{OHdG}$ in urine mostly used two or three steps of solid-phase extraction. ${ }^{9,19,20}$ The concentration effects of buffer A on SPE were investigated in the range $0-50 \mathrm{mM}$. It was found that 5 $\mathrm{mM} \mathrm{K \textrm {K } _ { 2 }} \mathrm{PO}_{4}$ buffer was suitable. It was reported that the recovery was dependent on the $\mathrm{pH}$ conditions of buffer $\mathrm{A}$; at $\mathrm{pH}$ 9, $8 \mathrm{OHdG}$ did not bind to the column. ${ }^{9}$ The influence of the $\mathrm{pH}$ was investigated in the range $5.5-8.5$; the most suitable $\mathrm{pH}$ was 7.5 , which agrees with another report. ${ }^{9}$ After eluting, using $\mathrm{CH}_{3} \mathrm{CN}$ to further eliminate protein can help avoid disturbing the trimethylsilylation. According to the eluate curve, $15 \%$ methanol in buffer A achieved a good recovery and a better cleanup procedure.

Using the optimal condition, the average recovery of $8 \mathrm{OHdG}$ in the extraction procedure from spiked urine was found to be $69.10 \%(n=5)$, which was similar to the recovery mentioned in another report. ${ }^{15}$

\section{Optimization of column temperature}

The column temperature in gas chromatography offers an important parameter that affects the separation efficiency. In this report, the optimal column temperature for the separation of $80 H d G$ from interfering urinary matrix components after the cleanup procedure was held at $210^{\circ} \mathrm{C}$ for $5 \mathrm{~min}$, raised at a rate of $10^{\circ} \mathrm{C} \mathrm{min}-1$ to $270^{\circ} \mathrm{C}$, and held for $5 \mathrm{~min}$. When the initial temperature was chosen to be $210^{\circ} \mathrm{C}$ held for $5 \mathrm{~min}$, the internal standard, pyrene, could be separated from other matrix components and the separation time was short. When using a temperature program raised at a rate of $7^{\circ} \mathrm{C} / \mathrm{min}$ to $270^{\circ} \mathrm{C}$, $8 \mathrm{OHdG}$ could not be completely separated from other urinary components (Fig. 1A); as the rate was decreased to $5^{\circ} \mathrm{C} / \mathrm{min}$, the resolution decreased (Fig. 1B). However, at a rate of $8^{\circ} \mathrm{C} / \mathrm{min}$, the resolution was improved (Fig. 1C). Furthermore, upon the rate to $10^{\circ} \mathrm{C} / \mathrm{min}$, the resolution was better and the separation time became shorter (Fig. 1D).

\section{Optimal derivatization condition of $80 \mathrm{HdG}$}

In this method, aliquots containing $0.5 \mu \mathrm{g}$ of $8 \mathrm{OHdG}$ were used to investigate the optimal derivatization reaction condition. The reaction conditions required for the best silylation involved 
Table 1 Recovery and precision of determination of $8 \mathrm{OHdG}$ in urine $(n=5)$

\begin{tabular}{rrrrc}
\hline $\begin{array}{l}\text { Added/ } \\
\mu \mathrm{g} \mathrm{ml}^{-1}\end{array}$ & $\begin{array}{c}\text { Measured/ } \mu \mathrm{g} \mathrm{ml}^{-1} \\
\text { (with S.D.) }\end{array}$ & RSD, \% & Recovery, \% $\begin{array}{c}\text { Average } \\
\text { recovery, \% }\end{array}$ \\
\hline 4 & $4.35 \pm 0.182$ & 4.18 & 108.75 & \\
8 & $7.58 \pm 0.230$ & 3.03 & 94.75 & 100.04 \\
16 & $15.46 \pm 1.266$ & 8.19 & 96.63 & \\
\hline
\end{tabular}

a study of time, temperature and the reagent concentration as well as the whole reaction volume. The optimum condition of normal nucleosides with BSTFA, reported by Gehrke and Patel, was heating at $150^{\circ} \mathrm{C}$ for $15 \mathrm{~min} .{ }^{16}$ However, an increase in the number of cap failures and leakage of the sample occurred at such a high silylation temperature. We found that derivatization could be accomplished at $100^{\circ} \mathrm{C}$ for $1 \mathrm{~h}$.

Under these reaction conditions, it was found that the whole reaction volume and reagent concentration were both important effects that influence the reaction yield. A study was carried out by varying the whole reaction volume while maintaining an acetonitrile-BSTFA volume ratio of $1: 1$. When the reaction volume/the weight of $8 \mathrm{OHdG}$ was $16 \mu \mathrm{l} / \mu \mathrm{g}$, the maximum RWR value was obtained. On the other hand, the acetonitrile-BSTFA volume ratio was investigated by varying the ratio from $1: 3$ to $3: 1$. When the volume ratio increased, the volume of BSTFA decreased and the silylation reaction could not be accomplished completely. However, as the volume ratio decreased, the volume of acetonitrile decreased and the sample could be solved incompletely; as a result, the reaction yield decreased. The optimal volume ratio was 1:2.

\section{Method evaluation}

The calibration graph of $8 \mathrm{OHdG}$ to pyrene peak-area ratio versus sample weight was found to be linear over sample weight range from $0.2 \mu \mathrm{g}$ to $100 \mu \mathrm{g}$, and the correlation coefficient was better than 0.995 . The detection limit of FID, defined as giving a response with a single-to-noise ratio of 3:1, was $4.56 \mathrm{pg} / \mathrm{s}$.

The interday and intraday coefficients of variation for $8 \mathrm{OHdG}$ were 10.27 and $14.62 \%$, respectively. Compared to another report (less than $5.4 \%),{ }^{18}$ the result was not very good, probably due to the microliter level of the derivatization reaction volume. Aliquots containing $250 \mu \mathrm{g}$ of nucleosides and a milliliter level reaction volume were used in that study.

\section{Analsis of $80 H d G$ in spiked urine}

By applying the optimal conditions, a typical gas chromatogram was obtained (Fig. 2), and a good separation was obtained for $8 \mathrm{OHdG}$ from other urinary matrix components. The peak was also identified by GC/MS. It was found that the most intense ion at $m / z, 383$ corresponded to the $\mathrm{B}+1$ (base +1 ) ion and the second most intense ion $\mathrm{m} / \mathrm{z} 368$, to the "base $+1-$ $\mathrm{CH}_{3}$ " ion. The ion at $\mathrm{m} / \mathrm{z}, 103$ usually occurred in the mass spectra of nucleosides, and served no diagonostic purpose. A molecular ion $\left(\mathrm{M}^{+} \cdot\right)$ and a characteristic $\left(\mathrm{M}^{+}-\mathrm{CH}_{3}\right)$ ion were observed at $m / z, 643$ and 628 , respectively; however, the relative intensity of these ions was rather weak. The result was identical to that discussed in Dizdaroglu's report. ${ }^{21}$

The recovery and precision were ascertained by adding
8OHdG standards to urine with known concentrations and analyzing the samples of each concentration. Table 1 gave the results.

In conclusion, a method for the analysis of urinary $8 \mathrm{OHdG}$ by GC and SPE was developed, which allowed an analysis of urinary $8 \mathrm{OHdG}$ with a single one-step extraction without any complex or time-consuming multiplex extraction steps. This method was successfully applied to the detection of $8 \mathrm{OHdG}$ in spiked urine. The recovery of spiked urine was $100.04 \%$ and the coefficients of variation were less than $8.19 \%$ for the analysis of urinary $8 \mathrm{OHdG}$. These were expected to be applied to the measurement of oxidative DNA damage.

\section{References}

1. Y. Kuchino, F. Mori, H. Kasai, H. Inone, S. Iwai, K. Miura, E. Ohtsuka, and S. Nishimura, Nature, 1987, 327, 77.

2. A. M. Maxam and W. M. Gilbert, Methods Enzymol., 1980, $65,499$.

3. E. S. Henle, Y. Luo, W. Gassman, and S. Lina, J. Biol. Chem., 1987, 272, 19633.

4. B. N. Ames and L. S. Gold, Mutat. Res., 1991, 250, 3.

5. M. Moriya and A. P. Grouman, Mol. Gen. Genet., 1993, 239,72 .

6. S. Shibutani, M. Takeshita, and A. P. Grollman, Nature, 1991, 349, 431.

7. R. P. Cunningham, Curr. Biol., 1997, 8, R576.

8. M. Hollstein, D. Sidransky, B. Vogelstein, and C. C. Harris, Science, 1991, 253, 49.

9. D. Germadnik, A. Pilger, and H. W. Rildiger, $J$. Chromatogr. B, 1997, 689, 399.

10. M. K. Shigenaga and B. N. Ames, Free Radic. Biol. Med., 1991, 10, 211.

11. J. Tchou and A. P. Grollman, Mutat. Res., 1993, 299, 277.

12. S. Loft, N. A. Fischer, I. B. Jeding, K. Vistisen, and H. E. Poulsen, J. Toxicol. Environ. Health, 1993, 40, 391.

13. T. Yamamoto, K. Hosokawa, T. Tamura, H. Kanno, I. Urabe, and H. Horjo, J. Obstet. Gynaecol. Res., 1996, 22, 359.

14. J. Leinonen, T. Lehtimaki, S. Toyokuni, K. Okada, T. Tanaka, H. Hiai, H. Ochi, P. Laippala, V. Rantalaiho, O. Wirta, A. Pasternack, and H. Alho, FEBS Lett., 1997, 417, 150.

15. A. J. R. Teixeira, M. R. Ferreira, W. J. van Dijk, G. van de Werken, and Ad P. J. M. de Jong, Anal. Biochem., 1995 , 226, 307.

16. D. S. Bergtold and M. G. Simic, Basic Life Sci., 1988, 49, 483.

17. C. W. Grehrke and C. D. Ruyle, J. Chromatogr., 1968, 38 , 473.

18. C. W. Gehrke and A. B. Patel, J. Chromatogr., 1976, 123, 335 .

19. M. K. Shigenaga, C. J. Gimeno, and B. N. Ames. Proc. Natl. Acad. Sci. USA, 1989, 86, 9697.

20. H. J. Helbock, K. B. Beckman, M. K. Shigenaga, P. B. Walter, A. A. Woodall, H. C. Yeo, and B. N. Ames, Proc. Natl. Acad. Sci. USA, 1998, 95, 288.

21. M. Dizdaroglu, Biochemistry, 1985, 24, 4476. 